\title{
Pemetaan Potensi Sumber Daya Perkebunan untuk Komoditas Strategis di Provinsi Jawa Barat
}

\author{
DIAN PERMATA RATNA SURI, INDRIANAWATI
}

\author{
Jurusan Teknik Geodesi \\ FTSP - Institut Teknologi Nasional, Bandung \\ Email: dianpermataratna@gmail.com
}

\begin{abstract}
ABSTRAK
Provinsi Jawa Barat memiliki tiga komoditas perkebunan, yaitu komoditas strategis, prospektif, dan unggulan spesifik lokal. Untuk mengoptimalkan potensi sumber daya perkebunan, diperlukan analisis potensi lahan agar dapat diketahui tingkat kesesuaian lahan komoditas perkebunan tertentu. Penelitian ini bertujuan untuk menganalisis potensi sumber daya perkebunan komoditas strategis di Provinsi Jawa Barat dengan metode scoring. Data yang digunakan sebagai parameter kesesuaian lahan, meliputi peta temperatur (hasil konversi dari peta kontur), peta curah hujan, peta lereng, peta drainase tanah, peta tekstur tanah, dan peta jenis tanah. Berdasarkan hasil penelitian, dapat diketahui bahwa mayoritas masing-masing wilayah kabupaten/kota di Provinsi Jawa Barat tidak mempunyai potensi sumber daya perkebunan komoditas strategis dengan tingkat kesesuaian lahan tertinggi yang sangat sesuai (S1), namun masing-masing wilayah mempunyai potensi untuk ditanam komoditas strategis dengan tingkatan kelas S2 (cukup sesuai) dan S3 (sesuai marginal), dimana jika akan ditanami komoditas tersebut, maka dibutuhkan perbaikan kualitas lahan berdasarkan faktor pembatas yang mempengaruhi.
\end{abstract}

Kata kunci: perkebunan, komoditas strategis, metode scoring, Provinsi Jawa Barat

\begin{abstract}
West Java Province has three plantation commodities, those are strategic commodities, prospective, and superior local specific commmodities. To optimize the potential of plantation resources, the analysis of the potential of land is required in order to know the level of land suitability of certain plantation commodities. This study has the objective to analyze the potential of plantation resource of strategic commodities in West Java province with a scoring method. The data used as land suitability parameters are temperature map (the conversion results of contour map), rainfall map, slope map, soil drainage map, soil texture map, and soil type map. Based on this study, it can be known that the majority of each region of the districts/cities in West Java Province does not have the potential of plantation resource of strategic commodities with highest level of land suitability which highly suitable (S1), but each region has the potential to be planted by strategic commodities in class S2 (moderately suitable) and S3 (marginal suitable) level, where if it will be planted with these commodities, it is necessary to improve the quality of land based on limiting factors that affect.
\end{abstract}

Keywords: plantation, strategic commodities, scoring method, West Java Province 


\section{PENDAHULUAN}

Perkebunan mempunyai peranan yang penting dan strategis dalam pembangunan daerah, terutama untuk meningkatkan kemakmuran dan kesejahteraan rakyat, penerimaan daerah, penyediaan lapangan kerja, perolehan nilai tambah, daya saing, pemenuhan kebutuhan konsumsi, dan bahan baku industri dalam negeri, serta optimalisasi pengelolaan sumber daya alam secara berkelanjutan. Menurut Undang-Undang Nomor 39 Tahun 2014 tentang Perkebunan, pengertian perkebunan adalah segala kegiatan yang mengusahakan tanaman tertentu pada tanah atau media tumbuh lainnya dalam ekosistem yang sesuai, mengolah dan memasarkan barang dan jasa hasil tanaman tersebut, dengan bantuan ilmu pengetahuan dan teknologi, permodalan, serta manajemen untuk mewujudkan kesejahteraan bagi pelaku usaha perkebunan dan masyarakat (Republik Indonesia, 2014).

Jawa Barat yang merupakan salah satu provinsi di Indonesia mempunyai luas wilayah sebesar 37.173,97 $\mathrm{km}^{2}$. Provinsi Jawa Barat memiliki kabupaten/kota yang berjumlah 27 kabupaten/kota terdiri atas 18 kabupaten dan 9 kota dengan 626 kecamatan dan 5.962 desa/kelurahan. Provinsi Jawa Barat mempunyai perkebunan yang dikelola oleh Perkebunan Besar Milik Negara dan Swasta serta Perkebunan Rakyat. Komoditas potensialnya adalah teh, kelapa sawit, tebu, dan karet (BPS Provinsi Jawa Barat, 2014). Berdasarkan Surat Keputusan Menteri Pertanian No: 3599/Kpts/PD.310/10/2009 tanggal 19 Oktober 2009 telah ditetapkan jenis komoditi binaan Direktorat Jenderal Perkebunan yaitu sebanyak 127 jenis, sedangkan yang dapat tumbuh dengan baik dan dapat dikembangkan serta dikelola secara intensif oleh Dinas Perkebunan Jawa Barat adalah sebanyak 31 jenis tanaman (Dinas Perkebunan Jawa Barat, 2014a). Provinsi Jawa Barat membagi 31 jenis tanaman perkebunan tersebut menjadi tiga komoditas perkebunan, yaitu komoditas strategis, prospektif, dan unggulan spesifik lokal (Dinas Perkebunan Jawa Barat, 2014b).

Bagi masyarakat Provinsi Jawa Barat pemahaman perkebunan dan agribisnis perkebunan kiranya telah lama dikuasai dan telah menjadi bagian persoalan kehidupan keseharian, oleh karena itu jika berbicara tentang kebijakan pembangunan sosial ekonomi masyarakat Provinsi Jawa Barat tentu saja tidak bisa terlepas dari pemikiran tentang bagaimana mengoptimalkan keberadaan potensi sumber daya perkebunan di Provinsi Jawa Barat yang cukup melimpah bagi upaya peningkatan kesejahteraan masyarakat Provinsi Jawa Barat secara keseluruhan. Analisis potensi lahan perkebunan sangat diperlukan di Provinsi Jawa Barat, karena dengan adanya informasi potensi lahan perkebunan dapat diketahui jenis pemanfaatan lahan yang sesuai untuk komoditas tertentu. Untuk mengatasi persoalan tersebut, maka dibutuhkan suatu penelitian mengenai pemetaan potensi sumber daya perkebunan di Provinsi Jawa Barat. Adapun pemetaan potensi sumber daya perkebunan yang akan dilakukan dalam penelitian ini adalah untuk komoditas strategis. Tujuan dari penelitian ini adalah untuk menganalisis potensi sumber daya perkebunan komoditas strategis di Provinsi Jawa Barat. Pemetaan dilakukan dengan menggunakan Sistem Informasi Geografis (SIG). Dari penelitian ini diharapkan dapat mengetahui lokasi lahan di Provinsi Jawa Barat yang berpotensi untuk dijadikan sebagai lahan perkebunan komoditas strategis.

\section{METODOLOGI}

Metode yang digunakan dalam penelitian adalah metode scoring. Metode scoring merupakan metode analisis kesesuaian lahan, dimana setiap parameter kesesuaian lahan diperhitungkan dengan pembobotan yang berbeda. Parameter yang digunakan dalam analisis kesesuaian lahan meliputi peta temperatur (hasil konversi dari peta kontur), peta curah hujan, peta 
lereng, peta drainase tanah, peta tekstur tanah, dan peta jenis tanah. Adapun diagram alir dari metodologi penelitian dapat dilihat pada Gambar 1.



Gambar 1 Diagram Alir Metodologi Penelitian

Dalam melakukan metode scoring, ada empat tahapan pembobotan yang dilakukan, yaitu (modifikasi dari Bakosurtanal, 2010):

a. Pembobotan Kesesuaian (Bob kes )

Tujuan dari pembobotan ini adalah untuk membedakan nilai pada tingkat kesesuaian agar bisa diperhitungkan dalam perhitungan akhir zonasi dengan menggunakan metode scoring. Pembobotan kesesuaian didefinisikan sebagai berikut:

1) $\mathrm{S} 1$ = sangat sesuai, bobot kesesuaian : 80

2) $\mathrm{S} 2$ = cukup sesuai, bobot kesesuaian : 60

3) $\mathrm{S3}=$ sesuai bersyarat, bobot kesesuian : 40

4) $\mathrm{N}=$ tidak sesuai, bobot kesesuain : 1

Pemberikan bobot kesesuaian pada penelitian dilakukan berdasarkan kriteria kesesuaian lahan untuk masing-masing tanaman komoditas strategis perkebunan. Kriteria kesesuaian lahan ini mengacu pada buku petunjuk teknis evaluasi lahan untuk komoditas pertanian oleh (Djaenudin dkk., 2003).

b. Pembobotan Parameter (Bob $\mathrm{par}$ )

Setiap parameter dalam analisis kesesuaian lahan mempunyai peran yang berbeda-beda, artinya parameter yang paling berpengaruh akan mempunyai bobot yang lebih tinggi dibandingkan yang kurang berpengaruh. Jumlah total dari semua bobot parameter adalah 100. Pada penelitian ini, seluruh parameter yang digunakan dianggap mempunyai pengaruh yang sama, sehingga bobot setiap parameter pada penelitian ini adalah 100/6.

c. Pembobotan Scoring $\left(\right.$ Bob $\left._{\text {score }}\right)$ 
Pembobotan scoring dilakukan untuk menghitung tingkat kesesuaian berdasarkan bobot kesesuaian (Bob kes) dan bobot parameter (Bob $\left.b_{\mathrm{par}}\right)$. Untuk parameter 1 sampai $\mathrm{n}$, perhitungannya menggunakan rumus 2.1 .

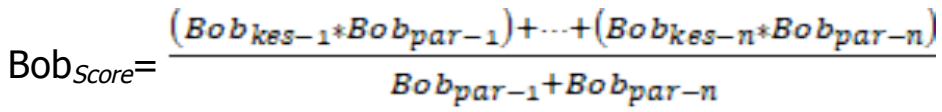

$$
\begin{aligned}
& \text { Keterangan : } \\
& \text { Bob }_{\text {score }}=\text { bobot scoring } \\
& \text { Bob }_{\text {kes }}=\text { bobot kesesuaian } \\
& \text { Bob }_{\text {par }}=\text { bobot parameter }
\end{aligned}
$$

Sebelum melakukan pembobotan scoring terlebih dahulu dilakukan proses overlay semua peta untuk setiap tanaman pada komoditas strategis, termasuk overlay dengan peta administrasi Provinsi Jawa Barat.

d. Kesesuaian scoring $\left(\operatorname{Kes}_{\text {score }}\right)$

Kesesuaian scoring ditetapkan berdasarkan nilai dari pembobotan scoring (Bob score) dengan perhitungan sebagai berikut:

1) S1 (sangat sesuai): apabila bobot scoring $\geq 80$

2) S2 (cukup sesuai): apabila bobot scoring antara 60 - 80

3) S3 (sesuai bersyarat): apabila bobot scoring antara $40-60$

4) N (tidak sesuai): apabila bobot scoring $<40$

\section{HASIL DAN ANALISIS}

\subsection{Hasil}

Hasil dari penelitian adalah peta potensi sumber daya perkebunan untuk 9 (sembilan) komoditas strategis di Provinsi Jawa Barat, yaitu cengkeh, kakao, karet, kelapa dalam, kopi arabika, kopi robusta, tebu, teh, dan tembakau. Berikut salah satu contoh hasil pemetaan potensi sumber daya perkebunan komoditas strategis di Provinsi Jawa Barat, yaitu untuk tanaman cengkeh yang dapat dilihat pada Gambar 2.

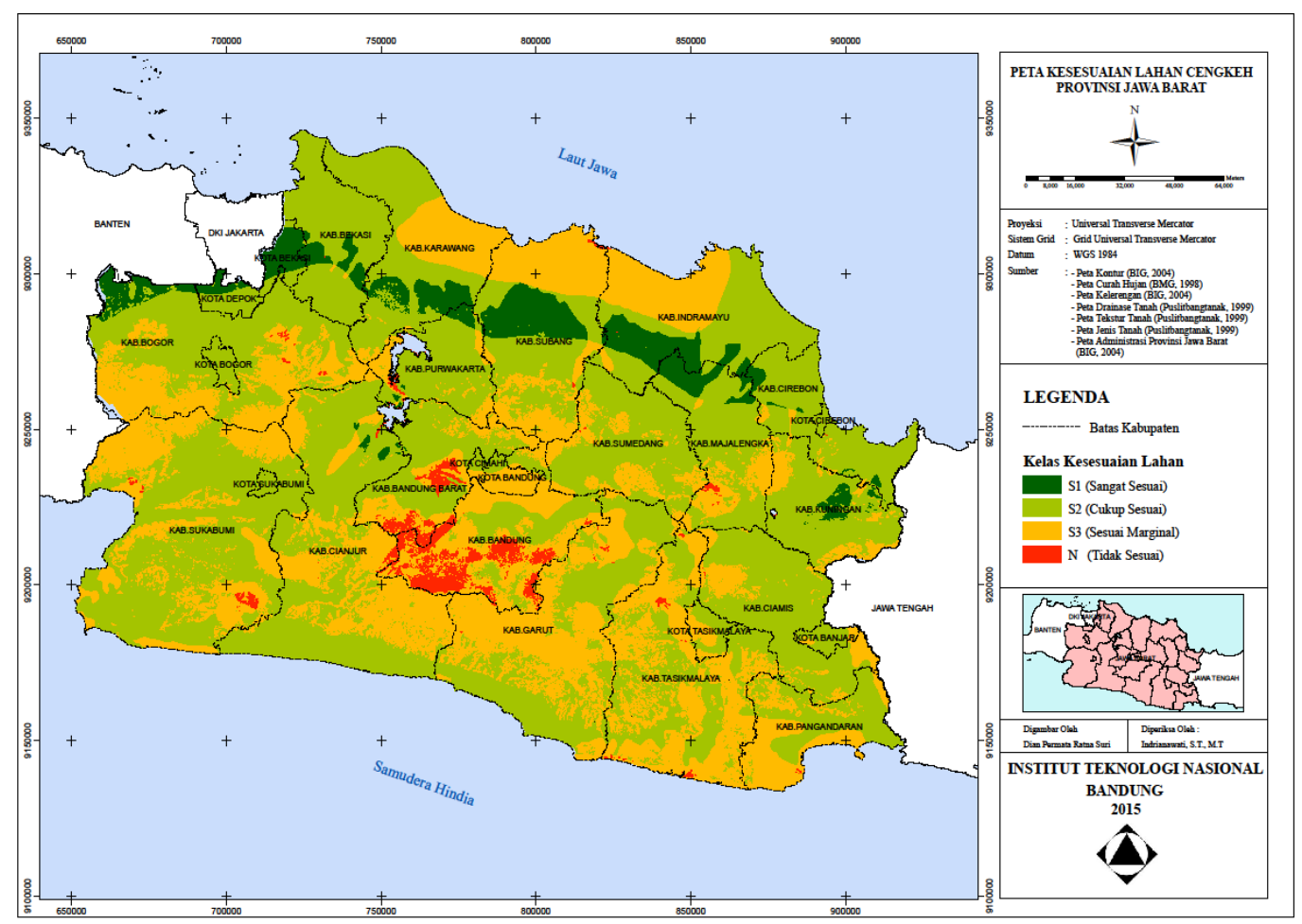

Gambar 2 Contoh Peta Potensi Sumber Daya Perkebunan di Provinsi Jawa Barat Untuk Tanaman Cengkeh

Reka Geomatika - 24 


\subsection{Analisis}

Analisis yang dilakukan meliputi analisis data, analisis pengolahan data, dan analisis potensi sumber daya perkebunan komoditas strategis di Provinsi Jawa Barat.

\subsubsection{Analisis Data}

Data yang digunakan pada penelitian ini meliputi peta administrasi (2004), peta kontur (2004), peta curah hujan (1998), peta lereng (2004), peta drainase tanah (1999), peta tekstur tanah (1999), dan peta jenis tanah (1999). Jika ditinjau berdasarkan tahun pembuatan peta yang digunakan, data/peta yang digunakan untuk menganalisis potensi sumber daya perkebunan komoditas strategis di Provinsi Jawa Barat ini memiliki tahun pembuatan yang berbeda-beda dan belum update. Seharusnya data yang digunakan untuk analisis kesesuaian lahan adalah data yang terbaru atau ter-update, karena berdasarkan studi literatur, salah satu jenis analisis kesesuaian lahan adalah kesesuaian lahan aktual, dimana analisis kesesuaian lahan tersebut merupakan analisis kesesuaian lahan yang dilakukan pada kondisi penggunaan lahan saat ini.

\subsubsection{Analisis Pengolahan Data}

Analisis pengolahan data dilakukan untuk menentukan tingkat kesesuaian lahan potensi sumber daya perkebunan komoditas strategis di Provinsi Jawa Barat. Tingkat kesesuaian lahan yang ditentukan, diklasifikasikan menjadi S1 (sangat sesuai), S2 (cukup sesuai), S3 (sesuai marginal atau bersyarat), dan $\mathrm{N}$ (tidak sesuai). Analisis tingkat kesesuaian lahan dilakukan dengan metode scoring menggunakan bantuan perangkat lunak ArcGIS. Sebelum semua data di-overlay, masing-masing data diberikan bobot kesesuaian berdasarkan syarat tumbuh tanaman dan bobot parameter. Bobot parameter yang diberikan pada penelitian ini mempunyai besaran yang sama, yaitu 100/6. Hal ini diberikan karena tidak ada acuan atau standardisasi yang mengatur tentang pembobotan parameter untuk analisis kesesuaian lahan perkebunan. Langkah selanjutnya adalah menghitung tingkat potensi kesesuaian lahan dengan pembobotan scoring. Berdasarkan hasil pembobotan scoring, selanjutnya menentukan tingkat kesesuaian lahan (kesesuaian scoring) dengan perhitungan sebagai berikut: sangat sesuai (S1) apabila nilai bobot scoring $\geq 80$, cukup sesuai (S2) apabila nilai bobot scoring antara 60-80, sesuai marginal (S3) apabila nilai bobot scoring antara 40-60, dan tidak sesuai $(\mathrm{N})$ apabila nilai bobot scoring $<40$.

\subsubsection{Analisis Potensi Sumber Daya Perkebunan Komoditas Strategis di Provinsi Jawa Barat Berdasarkan Masing-Masing Jenis Tanaman}

Analisis potensi sumber daya perkebunan komoditas strategis di Provinsi Jawa Barat ditentukan berdasarkan hasil analisis tingkat kesesuaian lahan yang telah dilakukan. Dengan catatan, analisis tingkat kesesuaian lahan yang telah dilakukan dalam penelitian ini, belum dievaluasi kesesuaian lahannya dengan menggunakan data penggunaan lahan atau penutup lahan saat ini. Adapun analisis potensi sumber daya perkebunan untuk masing-masing tanaman dari komoditas strategis di Provinsi Jawa Barat adalah sebagai berikut:

\section{a. Tanaman Cengkeh}

Jika ditinjau secara keseluruhan berdasarkan tingkat kesesuaian lahannya, potensi sumber daya perkebunan tanaman cengkeh di Provinsi Jawa Barat mempunyai tingkatan kelas S1 seluas 202.893 ha (5,5\% dari luas Provinsi Jawa Barat); S2 seluas 2.442 .855 ha (66,5\% dari luas Provinsi Jawa Barat); S3 seluas 988.670 ha (26,9\% dari luas Provinsi Jawa Barat); dan $\mathrm{N}$ seluas 40.644 ha $(1,1 \%$ dari luas Provinsi Jawa Barat). Adapun besaran dan persentase luas kesesuaian lahan tanaman cengkeh di Provinsi Jawa Barat dapat dilihat pada Tabel 2 dan Gambar 3. 
Tabel 2 Luas Kesesuaian Lahan Tanaman Cengkeh di Provinsi Jawa Barat

\begin{tabular}{|c|l|r|r|}
\hline No & Kelas Kesesuaian & \multicolumn{1}{c|}{ Luas (ha) } & Persentase (\%) \\
\hline 1. & S1 (sangat sesuai) & 202.893 & 5,5 \\
\hline 2. & S2 (cukup sesuai ) & 2.442 .855 & 66,5 \\
\hline 3. & S3 (sesuai marginal) & 988.670 & 26,9 \\
\hline 4. & N (tidak sesuai) & 40.644 & 1,1 \\
\hline \multicolumn{2}{|c|}{ Jumlah } & 3.675 .062 & 100 \\
\hline
\end{tabular}

Sumber: Hasil Analisis, 2015

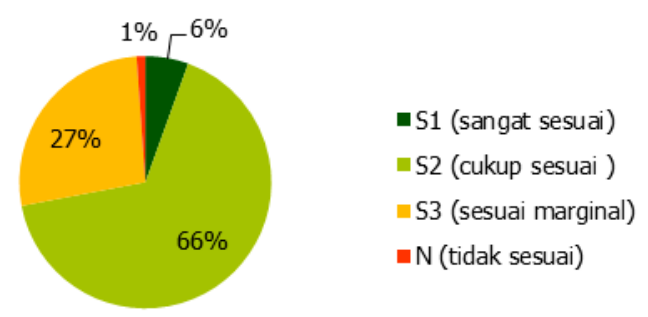

\section{Gambar 3. Persentase Luas Kesesuaian Lahan Tanaman Cengkeh di Provinsi Jawa Barat}

\section{b. Tanaman Kakao}

Jika ditinjau secara keseluruhan berdasarkan tingkat kesesuaian lahannya, potensi sumber daya perkebunan tanaman kakao di Provinsi Jawa Barat mempunyai tingkatan kelas S1 seluas 0 ha ( $0 \%$ dari luas Provinsi Jawa Barat); S2 seluas 1.670 .760 ha (45,5\% dari luas Provinsi Jawa Barat); S3 seluas 1.734 .758 ha (47,2\% dari luas Provinsi Jawa Barat); dan N sebesar 269.544 ha (7,3\% dari luas Provinsi Jawa Barat). Adapun besaran dan persentase luas kesesuaian lahan tanaman kakao di Provinsi Jawa Barat dapat dilihat pada Tabel 3 dan Gambar 4.

Tabel 3 Luas Kesesuaian Lahan Tanaman Kakao di Provinsi Jawa Barat

\begin{tabular}{|c|l|r|r|}
\hline No & Kelas Kesesuaian & \multicolumn{1}{|c|}{ Luas (ha) } & \multicolumn{1}{c|}{ Persentase (\%) } \\
\hline 1. & S1 (sangat sesuai) & 0 & 0,0 \\
\hline 2. & S2 (cukup sesuai ) & 1.670 .760 & 45,5 \\
\hline 3. & S3 (sesuai marginal) & 1.734 .758 & 47,2 \\
\hline 4. & N (tidak sesuai) & 269.544 & 7,3 \\
\hline \multicolumn{2}{|c|}{ Jumlah } & 3.675 .062 & 100 \\
\hline
\end{tabular}

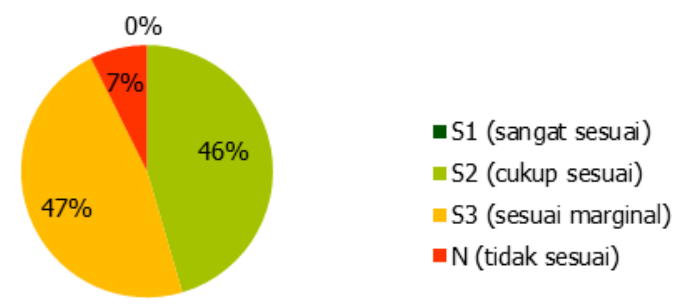

\section{Gambar 4 Persentase Luas Kesesuaian Lahan Tanaman Kakao di Provinsi Jawa Barat}

\section{c. Tanaman Karet}

Jika ditinjau secara keseluruhan berdasarkan tingkat kesesuaian lahannya, potensi sumber daya perkebunan tanaman karet di Provinsi Jawa Barat mempunyai tingkatan kelas S1 seluas 
117.105 ha (3,2\% dari luas Provinsi Jawa Barat); S2 seluas 1.432 .525 ha (39,0\% dari luas Provinsi Jawa Barat); S3 seluas 1.868.509,50 ha (50,8\% dari luas Provinsi Jawa Barat); dan $\mathrm{N}$ seluas 256.923 ha (7,0\% dari luas Provinsi Jawa Barat). Adapun besaran dan persentase luas kesesuaian lahan tanaman karet di Provinsi Jawa Barat dapat dilihat pada Tabel 4 dan Gambar 5.

Tabel 4 Luas Kesesuaian Lahan Tanaman Karet di Provinsi Jawa Barat

\begin{tabular}{|c|l|r|r|}
\hline No & \multicolumn{1}{|c|}{ Kelas Kesesuaian } & \multicolumn{1}{c|}{ Luas (ha) } & Persentase (\%) \\
\hline 1. & S1 (sangat sesuai) & 117.105 & 3,2 \\
\hline 2. & S2 (cukup sesuai ) & 1.432 .525 & 39,0 \\
\hline 3. & S3 (sesuai marginal) & 1.868 .510 & 50,8 \\
\hline 4. & N (tidak sesuai) & 256.923 & 7,0 \\
\hline \multicolumn{2}{|c|}{ Jumlah } & 3.675 .062 & 100 \\
\hline
\end{tabular}

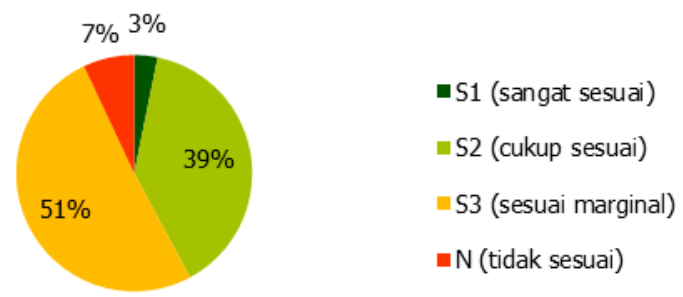

\section{Gambar 5 Persentase Luas Kesesuaian Lahan Tanaman Karet di Provinsi Jawa Barat}

\section{d. Tanaman Kelapa Dalam}

Jika ditinjau secara keseluruhan berdasarkan tingkat kesesuaian lahannya, potensi sumber daya perkebunan tanaman kelapa dalam di Provinsi Jawa Barat mempunyai tingkatan kelas S1 seluas 0 ha (0\% dari luas Provinsi Jawa Barat); S2 seluas 2.057 .696 ha, $(55,1 \%$ dari luas Provinsi Jawa Barat); S3 seluas 1.449 .193 ha (40,2\% dari luas Provinsi Jawa Barat); dan N seluas 168.174 ha (4,7\% dari luas Provinsi Jawa Barat). Adapun besaran dan persentase luas kesesuaian lahan tanaman kelapa dalam di Provinsi Jawa Barat dapat dilihat pada Tabel 5 dan Gambar 6.

\section{Tabel 5 Luas Kesesuaian Lahan Tanaman Kelapa Dalam di Provinsi Jawa Barat}

\begin{tabular}{|c|l|r|r|}
\hline No & Kelas Kesesuaian & \multicolumn{1}{c|}{ Luas (ha) } & \multicolumn{1}{c|}{ Persentase (\%) } \\
\hline 1. & S1 (sangat sesuai) & 0 & 0,0 \\
\hline 2. & S2 (cukup sesuai ) & 2.057 .696 & 55,1 \\
\hline 3. & S3 (sesuai marginal) & 1.449 .193 & 40,2 \\
\hline 4. & N (tidak sesuai) & 168.174 & 4,7 \\
\hline \multicolumn{2}{|c|}{ Jumlah } & 3.675 .062 & 100 \\
\hline
\end{tabular}

Sumber: Hasil Analisis, 2015

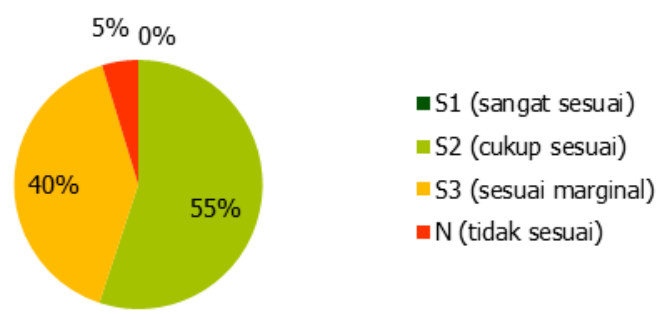

Gambar 6 Persentase Luas Kesesuaian Lahan Tanaman Kelapa Dalam di Provinsi Jawa Barat 


\section{e. Tanaman Kopi Arabika}

Jika ditinjau secara keseluruhan berdasarkan tingkat kesesuaian lahannya, potensi sumber daya perkebunan tanaman kopi arabika di Provinsi Jawa Barat mempunyai tingkatan kelas S1 seluas 17.140 ha ( $0 \%$ dari luas Provinsi Jawa Barat); S2 seluas 1.393 .043 ha, (37,9\% dari luas Provinsi Jawa Barat); S3 seluas 2.004.229 ha (54,5\% dari luas Provinsi Jawa Barat); dan N seluas 260.649 ha (7,1\% dari luas Provinsi Jawa Barat). Adapun besaran dan persentase luas kesesuaian lahan tanaman kopi arabika di Provinsi Jawa Barat dapat dilihat pada Tabel 6 dan Gambar 7.

\section{Tabel 6 Luas Kesesuaian Lahan Tanaman Kopi Arabika di Provinsi Jawa Barat}

\begin{tabular}{|c|l|r|r|}
\hline No & Kelas Kesesuaian & \multicolumn{1}{c|}{ Luas (ha) } & Persentase (\%) \\
\hline 1. & S1 (sangat sesuai) & 17.140 & 0,5 \\
\hline 2. & S2 (cukup sesuai ) & 1.393 .043 & 37,9 \\
\hline 3. & S3 (sesuai marginal) & 2.004 .229 & 54,5 \\
\hline 4. & N (tidak sesuai) & 260.649 & 7,1 \\
\hline \multicolumn{2}{|c|}{ Jumlah } & 3.675 .062 & 100 \\
\hline
\end{tabular}

Sumber: Hasil Analisis, 2015

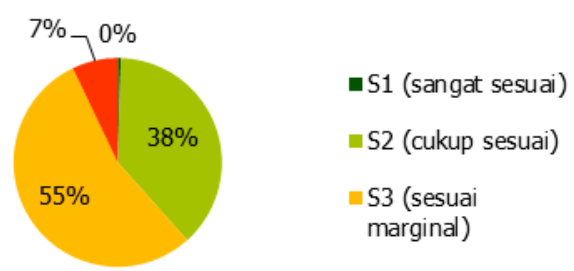

\section{Gambar 7 Persentase Luas Kesesuaian Lahan Tanaman Kopi Arabika di Provinsi Jawa Barat}

\section{f. Tanaman Kopi Robusta}

Jika ditinjau secara keseluruhan berdasarkan tingkat kesesuaian lahannya, potensi sumber daya perkebunan tanaman kopi robusta di Provinsi Jawa Barat mempunyai tingkatan kelas S1 seluas 117.665 ha (3,2\% dari luas Provinsi Jawa Barat); S2 seluas 1.779 .228 ha $(48,4 \%$ dari luas Provinsi Jawa Barat); S3 seluas 1.531 .790 ha (41,7\% dari luas Provinsi Jawa Barat); dan N seluas 246.380 ha (6,7\% dari luas Provinsi Jawa Barat). Adapun besaran dan persentase luas kesesuaian lahan tanaman kopi robusta di Provinsi Jawa Barat dapat dilihat pada Tabel 7. dan Gambar 8.

Tabel 7 Luas Kesesuaian Lahan Tanaman Kopi Robusta di Provinsi Jawa Barat

\begin{tabular}{|c|l|r|r|}
\hline No & Kelas Kesesuaian & \multicolumn{1}{c|}{ Luas (ha) } & \multicolumn{1}{c|}{ Persentase (\%) } \\
\hline 1. & S1 (sangat sesuai) & 117.665 & 3,2 \\
\hline 2. & S2 (cukup sesuai ) & 1.779 .228 & 48,4 \\
\hline 3. & S3 (sesuai marginal) & 1.531 .790 & 41,7 \\
\hline 4. & N (tidak sesuai) & 246.380 & 6,7 \\
\hline \multicolumn{2}{|c|}{ Jumlah } & 3.675 .062 & 100 \\
\hline
\end{tabular}

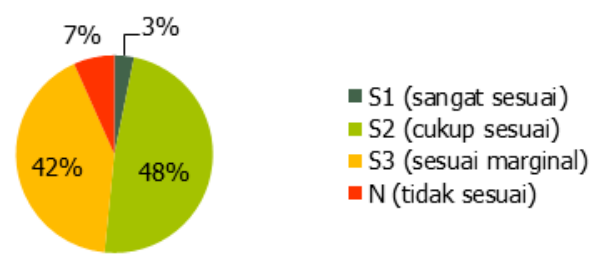

Gambar 8 Persentase Luas Kesesuaian Lahan Tanaman Kopi Robusta di Provinsi Jawa Barat 


\section{g. Tanaman Tebu}

Jika ditinjau secara keseluruhan berdasarkan tingkat kesesuaian lahannya, potensi sumber daya perkebunan tanaman tebu di Provinsi Jawa Barat mempunyai tingkatan kelas S1 seluas 24.294 ha $(0,7 \%$ dari luas Provinsi Jawa Barat); S2 seluas 1.542 .356 ha ( $42,0 \%$ dari luas Provinsi Jawa Barat); S3 seluas 1.956 .015 ha (53,2\% dari luas Provinsi Jawa Barat); dan N seluas 152.397 ha (4,2\% dari luas Provinsi Jawa Barat). Adapun besaran dan persentase luas kesesuaian lahan tanaman tebu di Provinsi Jawa Barat dapat dilihat pada Tabel 8 dan Gambar 9.

\section{Tabel 8 Luas Kesesuaian Lahan Tanaman Tebu di Provinsi Jawa Barat}

\begin{tabular}{|c|l|r|r|}
\hline No & \multicolumn{1}{|c|}{ Kelas Kesesuaian } & \multicolumn{1}{c|}{ Luas (ha) } & Persentase (\%) \\
\hline 1. & S1 (sangat sesuai) & 24.294 & 0,7 \\
\hline 2. & S2 (cukup sesuai ) & 1.542 .356 & 42,0 \\
\hline 3. & S3 (sesuai marginal) & 1.956 .015 & 53,2 \\
\hline 4. & N (tidak sesuai) & 152.397 & 4,2 \\
\hline \multicolumn{2}{|c|}{ Jumlah } & 3.675 .062 & 100 \\
\hline
\end{tabular}

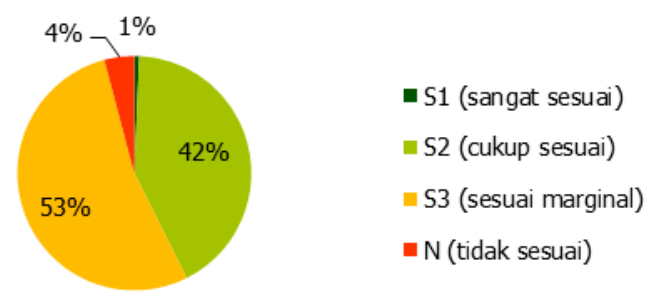

\section{Gambar 9 Persentase Luas Kesesuaian Lahan Tanaman Tebu di Provinsi Jawa Barat}

\section{h. Tanaman Teh}

Jika ditinjau secara keseluruhan berdasarkan tingkat kesesuaian lahannya, potensi sumber daya perkebunan tanaman teh di Provinsi Jawa Barat mempunyai tingkatan kelas S1 seluas 25.467 ha (0,7\% dari luas Provinsi Jawa Barat); S2 seluas 2.153 .275 ha (58,6\% dari luas Provinsi Jawa Barat); S3 seluas 1.468 .723 ha (40,0\% dari luas Provinsi Jawa Barat); dan N seluas 27.597 ha $(0,8 \%$ dari luas Provinsi Jawa Barat). Adapun besaran dan persentase luas kesesuaian lahan tanaman teh di Provinsi Jawa Barat dapat dilihat pada Tabel 9 dan Gambar 10 .

Tabel 9 Luas Kesesuaian Lahan Tanaman Teh di Provinsi Jawa Barat

\begin{tabular}{|c|l|r|r|}
\hline No & Kelas Kesesuaian & \multicolumn{1}{c|}{ Luas (ha) } & Persentase (\%) \\
\hline 1. & S1 (sangat sesuai) & 25.467 & 0,7 \\
\hline 2. & S2 (cukup sesuai ) & 2.153 .275 & 58,6 \\
\hline 3. & S3 (sesuai marginal) & 1.468 .723 & 40,0 \\
\hline 4. & N (tidak sesuai) & 27.597 & 0,8 \\
\hline \multicolumn{2}{|c|}{ Jumlah } & 3.675 .062 & 100 \\
\hline
\end{tabular}

Sumber: Hasil Analisis, 2015

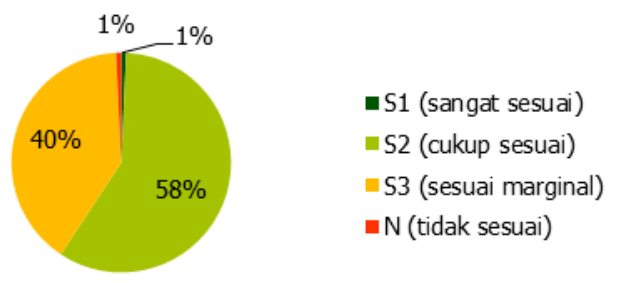

Gambar 10 Persentase Luas Kesesuaian Lahan Tanaman Teh di Provinsi Jawa Barat 


\section{i. Tanaman Tembakau}

Jika ditinjau secara keseluruhan berdasarkan tingkat kesesuaian lahannya, potensi sumber daya perkebunan tanaman tembakau di Provinsi Jawa Barat mempunyai tingkatan kelas S1 seluas 0 ha ( $0 \%$ dari luas Provinsi Jawa Barat); S2 seluas 2.559 .433 ha (69,6\% dari luas Provinsi Jawa Barat); S3 seluas 1.105 .487 ha (30,1\% dari luas Provinsi Jawa Barat); dan N seluas 10.142 ha (0,3\% dari luas Provinsi Jawa Barat). Adapun besaran dan persentase luas kesesuaian lahan tanaman tembakau di Provinsi Jawa Barat dapat dilihat pada Tabel 10 dan Gambar 11.

\section{Tabel 10 Luas Kesesuaian Lahan Tanaman Tembakau di Provinsi Jawa Barat}

\begin{tabular}{|c|l|r|r|}
\hline No & Kelas Kesesuaian & \multicolumn{1}{|c|}{ Luas (ha) } & \multicolumn{1}{|c|}{ Persentase (\%) } \\
\hline 1. & S1 (sangat sesuai) & 0 & 0,0 \\
\hline 2. & S2 (cukup sesuai ) & 2.559 .433 & 69,6 \\
\hline 3. & S3 (sesuai marginal) & 1.105 .487 & 30,1 \\
\hline 4. & N (tidak sesuai) & 10.142 & 0,3 \\
\hline \multicolumn{2}{|c|}{ Jumlah } & 3.675 .062 & 100 \\
\hline
\end{tabular}

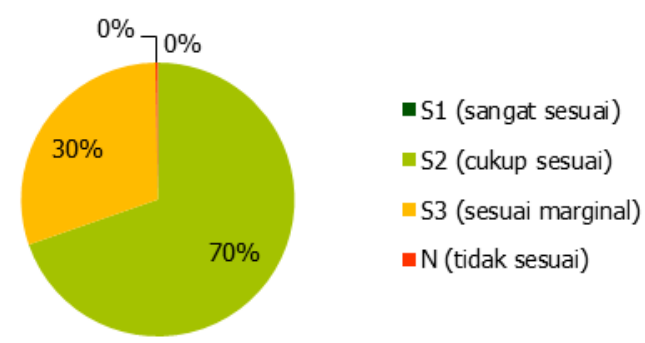

\section{Gambar 11 Persentase Luas Kesesuaian Lahan Tanaman Tembakau di Provinsi Jawa Barat}

\subsubsection{Analisis Potensi Sumber Daya Perkebunan Komoditas Strategis di Provinsi}

Berdasarkan analisis tingkat kesesuaian lahan yang telah dilakukan, dapat diketahui informasi persentase potensi tingkat kesesuaian lahan komoditas strategis di Provinsi Jawa Barat berdasarkan luas wilayah Provinsi Jawa Barat, seperti yang dapat dilihat pada Tabel 2 s.d Tabel 10. Selain informasi tersebut, dapat juga diperoleh informasi jenis-jenis tanaman perkebunan komoditas strategis yang berpotensi di masing-masing wilayah kabupaten/kota di Provinsi Jawa Barat. Informasi jenis tanaman tersebut diperoleh berdasarkan tingkat kesesuaian lahan yang tertinggi di masing-masing wilayah kabupaten/kota, seperti yang dapat dilihat pada Tabel 11.

Tabel 11 Potensi Sumber Daya Perkebunan Komoditas Strategis di Provinsi Jawa Barat Berdasarkan Tingkat Kesesuaian Lahan yang Tertinggi di Masing-Masing Wilayah Kabupaten/Kota

\begin{tabular}{|c|c|c|c|c|c|}
\hline \multirow{2}{*}{ No } & \multirow{2}{*}{ Kab/Kota } & \multicolumn{4}{|c|}{ Tanaman Komoditas Strategis } \\
\hline & & Kelas S1 & Kelas S2 & Kelas S3 & Kelas N \\
\hline 1. & Kab. Bandung & - & - & $\begin{array}{l}\text { Cengkeh, Kelapa Dalam, } \\
\text { Kopi Arabika, Kopi } \\
\text { Robusta, Tebu, } \\
\text { Tembakau,Teh }\end{array}$ & Kakao, Karet \\
\hline 2. & $\begin{array}{l}\text { Kab.Bandung } \\
\text { Barat }\end{array}$ & - & $\begin{array}{l}\text { Cengkeh, Karet, Kopi } \\
\text { Arabika, Kopi Robusta, } \\
\text { Tebu, Tembakau,Teh }\end{array}$ & Kakao, Kelapa Dalam & - \\
\hline 3. & Kab. Bekasi & - & $\begin{array}{l}\text { Cengkeh, Kakao, Kelapa } \\
\text { Dalam, Tembakau }\end{array}$ & $\begin{array}{l}\text { Karet, Kopi Arabika, Kopi } \\
\text { Robusta, Tebu, Teh }\end{array}$ & - \\
\hline
\end{tabular}


Tabel 11 Potensi Sumber Daya Perkebunan Komoditas Strategis di Provinsi Jawa Barat Berdasarkan Tingkat Kesesuaian Lahan yang Tertinggi di Masing-Masing Wilayah Kabupaten/Kota (Lanjutan)

\begin{tabular}{|c|c|c|c|c|c|}
\hline \multirow{2}{*}{ No } & \multirow{2}{*}{ Kab/Kota } & \multicolumn{4}{|c|}{ Tanaman Komoditas Strategis } \\
\hline & & Kelas S1 & Kelas S2 & Kelas S3 & Kelas $\mathbf{N}$ \\
\hline 4. & Kab. Bogor & 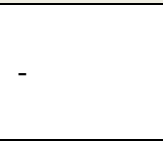 & $\begin{array}{l}\text { Cengkeh, Karet, Kelapa } \\
\text { Dalam, Kopi Arabika, Kopi } \\
\text { Robusta, Tebu, } \\
\text { Tembakau,Teh }\end{array}$ & Kakao & - \\
\hline 5. & Kab. Ciamis & - & $\begin{array}{l}\text { Cengkeh, Karet, Kelapa } \\
\text { Dalam, Kopi Arabika, Kopi } \\
\text { Robusta, Tebu, } \\
\text { Tembakau,Teh }\end{array}$ & Kakao & - \\
\hline 6. & Kab. Cianjur & - & $\begin{array}{l}\text { Cengkeh, Karet, Kopi } \\
\text { Arabika, Kopi Robusta, } \\
\text { Tebu, Tembakau,Teh }\end{array}$ & Kakao, Kelapa Dalam & - \\
\hline 7. & Kab. Cirebon & - & $\begin{array}{l}\text { Cengkeh, Kakao, Kelapa } \\
\text { Dalam, Tembakau }\end{array}$ & $\begin{array}{l}\text { Karet, Kopi Arabika, Kopi } \\
\text { Robusta, Tebu, Teh }\end{array}$ & - \\
\hline 8. & Kab. Garut & - & $\begin{array}{l}\text { Cengkeh, Tebu, } \\
\text { Tembakau,Teh }\end{array}$ & $\begin{array}{l}\text { Kakao, Karet, Kelapa } \\
\text { Dalam, Kopi Arabika, Kopi } \\
\text { Robusta }\end{array}$ & - \\
\hline 9. & Kab. Indramayu & - & $\begin{array}{l}\text { Cengkeh, Kakao, Kelapa } \\
\text { Dalam, Tembakau }\end{array}$ & $\begin{array}{l}\text { Karet, Kopi Arabika, Kopi } \\
\text { Robusta, Tebu, Teh }\end{array}$ & - \\
\hline 10. & Kab. Karawang & - & $\begin{array}{l}\text { Cengkeh, Kakao, Kelapa } \\
\text { Dalam, Tembakau }\end{array}$ & $\begin{array}{l}\text { Karet, Kopi Arabika, Kopi } \\
\text { Robusta, Tebu, Teh }\end{array}$ & - \\
\hline 11. & Kab. Kuningan & - & $\begin{array}{l}\text { Cengkeh, Kakao, Kelapa } \\
\text { Dalam, Kopi Robusta, } \\
\text { Tembakau,Teh }\end{array}$ & Karet, Kopi Arabika, Tebu & - \\
\hline 12. & Kab. Majalengka & - & $\begin{array}{l}\text { Cengkeh, Kakao, Karet, } \\
\text { Kelapa Dalam, Kopi } \\
\text { Robusta, Tebu, } \\
\text { Tembakau,Teh } \\
\end{array}$ & Kopi Arabika & - \\
\hline 13. & Kab. Pangandaran & - & $\begin{array}{l}\text { Cengkeh, Kelapa Dalam, } \\
\text { Tembakau }\end{array}$ & $\begin{array}{l}\text { Cengkeh, Kakao, Kopi } \\
\text { Arabika, Kopi Robusta, } \\
\text { Tebu, Teh }\end{array}$ & - \\
\hline 14. & Kab. Purwakarta & - & $\begin{array}{l}\text { Cengkeh, Kakao, Karet, } \\
\text { Kelapa Dalam, Kopi } \\
\text { Arabika, Kopi Robusta, } \\
\text { Tembakau,Teh }\end{array}$ & Tebu & - \\
\hline 15. & Kab. Subang & - & $\begin{array}{l}\text { Cengkeh, Kakao, Kelapa } \\
\text { Dalam, Kopi Robusta, } \\
\text { Tebu, Tembakau,Teh }\end{array}$ & Karet, Kopi Arabika & - \\
\hline 16. & Kab. Sukabumi & - & $\begin{array}{l}\text { Cengkeh, Karet, Kopi } \\
\text { Arabika, Kopi Robusta, } \\
\text { Teh }\end{array}$ & $\begin{array}{l}\text { Kakao, Kelapa Dalam, } \\
\text { Tebu, Tembakau }\end{array}$ & - \\
\hline 17. & Kab. Sumedang & - & $\begin{array}{l}\text { Cengkeh, Karet, Kelapa } \\
\text { Dalam, Kopi Arabika, Kopi } \\
\text { Robusta, Teh }\end{array}$ & Kakao, Tebu, Tembakau & - \\
\hline 18. & Kab. Tasikmalaya & - & Cengkeh, Tembakau & $\begin{array}{l}\text { Kakao, Karet, Kelapa } \\
\text { Dalam, Kopi Arabika, Kopi } \\
\text { Robusta, Tebu, Teh }\end{array}$ & - \\
\hline 19. & Kota Bandung & - & $\begin{array}{l}\text { Kakao, Kelapa Dalam, } \\
\text { Tembakau }\end{array}$ & $\begin{array}{l}\text { Cengkeh, Karet, Kopi } \\
\text { Arabika, Kopi Robusta, } \\
\text { Tebu, Teh }\end{array}$ & - \\
\hline 20. & Kota Banjar & - & $\begin{array}{l}\text { Cengkeh, Kakao, Karet, } \\
\text { Kelapa Dalam, Tebu, } \\
\text { Tembakau,Teh }\end{array}$ & Kopi Arabika, Kopi Robusta & - \\
\hline 21. & Kota Bekasi & Cengkeh & $\begin{array}{l}\text { Kakao, Karet, Kelapa } \\
\text { Dalam, Kopi Arabika, Kopi } \\
\text { Robusta, Tebu, } \\
\text { Tembakau,Teh }\end{array}$ & - & - \\
\hline 22. & Kota Bogor & - & $\begin{array}{l}\text { Cengkeh, Kakao, Karet, } \\
\text { Kelapa Dalam, Kopi } \\
\text { Arabika, Kopi Robusta, } \\
\text { Tebu, Tembakau,Teh }\end{array}$ & - & - \\
\hline 23. & Kota Cimahi & $\begin{array}{l}\text { Kopi } \\
\text { Arabika }\end{array}$ & $\begin{array}{l}\text { Cengkeh, Kakao, Karet, } \\
\text { Kopi Robusta, Tebu, } \\
\text { Tembakau,Teh }\end{array}$ & Kelapa Dalam & - \\
\hline
\end{tabular}


Tabel 11 Potensi Sumber Daya Perkebunan Komoditas Strategis di Provinsi Jawa Barat Berdasarkan Tingkat Kesesuaian Lahan yang Tertinggi di Masing-Masing Wilayah Kabupaten/Kota (Lanjutan)

\begin{tabular}{|c|l|l|l|l|l|}
\hline \multirow{2}{*}{ No } & \multicolumn{1}{|c|}{ Kab/Kota } & \multicolumn{3}{c|}{ Tanaman Komoditas Strategis } \\
\cline { 3 - 6 } 24. & Kota Cirebon & - & \multicolumn{1}{c|}{ Kelas S2 } & \multicolumn{1}{c|}{ Kelas S3 } \\
\hline 25. & Kota Depok & - & $\begin{array}{l}\text { Cengkeh, Kakao, Kelapa } \\
\text { Dalam, Tebu, Tembakau }\end{array}$ & $\begin{array}{l}\text { Karet, Kopi Arabika, Kopi } \\
\text { Robusta, Teh }\end{array}$ & - \\
\hline 26. & Kota Sukabumi & $\begin{array}{l}\text { Kengkeh, Kakao, Karet, } \\
\text { Kelapa Dalam, Kopi } \\
\text { Arabika, Kopi Robusta, } \\
\text { Tebu, Tembakau,Teh }\end{array}$ & - & - \\
\hline Robusta & $\begin{array}{l}\text { Cengkeh, Kakao, Karet, } \\
\text { Kelapa Dalam, Kopi } \\
\text { Arabika, Tembakau,Teh }\end{array}$ & Tebu & - \\
\hline Kota Tasikmalaya & - & $\begin{array}{l}\text { Cengkeh, Karet, Kelapa } \\
\text { Dalam, Kopi Robusta, } \\
\text { Tembakau,Teh }\end{array}$ & Kakao, Kopi Arabika, Tebu & - \\
\hline
\end{tabular}

Berdasarkan Tabel 11, dapat diketahui bahwa di Kabupaten Bandung tidak mempunyai jenis tanaman komoditas strategis yang sangat sesuai untuk ditanam (S1) dan cukup sesuai (S2), serta mempunyai jenis tanaman yang tidak sesuai $(\mathrm{N})$, yaitu kakao dan karet. Di Kota Bekasi mempunyai jenis tanaman dengan tingkat kesesuaian lahan tertinggi yang sangat sesuai (S1) untuk ditanam, yaitu cengkeh; Kota Cimahi mempunyai jenis tanaman yang sangat sesuai (S1), yaitu kopi arabika; dan Kota Sukabumi mempunyai jenis tanaman yang sangat sesuai (S1), yaitu kopi robusta. Jika dilihat secara mayoritas, masing-masing wilayah kabupaten/kota di Provinsi Jawa Barat tidak mempunyai jenis tanaman komoditas strategis dengan tingkat kesesuaian lahan tertinggi yang sangat sesuai untuk ditanam (S1), namun masing-masing wilayah mempunyai potensi untuk ditanam komoditas strategis dengan tingkatan kelas S2 (cukup sesuai) dan S3 (sesuai marginal), dimana masing-masing jenis tanaman komoditas strategis ini mempunyai beberapa faktor pembatas yang membutuhkan perbaikan kualitas lahan jika akan ditanami komoditas tersebut.

\section{KESIMPULAN}

Berdasarkan hasil pemetaan dan analisis tingkat kesesuaian lahan yang telah dilakukan, dapat diketahui bahwa persentase potensi tingkat kesesuaian lahan sumber daya perkebunan komoditas strategis di Provinsi Jawa Barat berdasarkan luas wilayah Provinsi Jawa Barat, terdiri dari tingkatan yang sangat sesuai (S1) meliputi cengkeh (5,52\%), kakao $(0 \%)$, karet $(3,19 \%)$, kelapa dalam $(0 \%)$, kopi arabika $(0,47 \%)$, kopi robusta $(3,20 \%)$, tebu $(0,66 \%)$, tembakau $(0 \%)$, dan teh $(0,69 \%)$; tingkatan cukup sesuai (S2) meliputi cengkeh $(66,47 \%)$, kakao $(45,46 \%)$, karet $(38,98 \%)$, kelapa dalam $(55,10 \%)$, kopi arabika $(37,91 \%)$, kopi robusta $(37,91 \%)$, tebu $(41,97 \%)$, tembakau $(69,64 \%)$, dan teh $(58,59)$; tingkatan sesuai marginal (S3) meliputi cengkeh $(26,90 \%)$, kakao $(47,20 \%)$, karet $(50,84 \%)$, kelapa dalam $(40,18 \%)$, kopi arabika $(54,54 \%)$, kopi robusta $(41,68 \%)$, tebu $(53,22 \%)$, tembakau $(30,08 \%)$, dan teh $(39,96 \%)$; dan tingkatan tidak sesuai $(\mathrm{N})$ meliputi cengkeh $(1,11 \%)$, kakao $(7,33 \%)$, karet $(6,99 \%)$, kelapa dalam $(4,72 \%)$, kopi arabika $(7,09 \%)$, kopi robusta $(6,70 \%)$, tebu $(4,15 \%)$, tembakau $(0,28 \%)$, dan teh $(0,75 \%)$. 


\section{DAFTAR PUSTAKA}

Bakosurtanal (Badan Koordinasi Survei dan Pemetaan Nasional). (2010). Kajian Potensi Sumberdaya Pesisir Kabupaten Rokan Hilir. Cibinong, Pusat Survei Sumber Daya Alam Laut Bakosurtanal.

BPS Provinsi Jawa Barat. (2014). Jawa Barat Dalam Angka 2014. Bandung, BPS Provinsi Jawa Barat.

Dinas Perkebunan Jawa Barat. (2014a). Analisis dan Visualisasi Potensi Sumberdaya Perkebunan. Laporan Akhir. Bandung, Dinas Perkebunan Jawa Barat.

Dinas Perkebunan Jawa Barat. (2014b). Komoditas Perkebunan. Dipetik 27 April 2015 dari http://disbun.jabarprov.go.id/index.php/komoditas_strategis pada tanggal 27 April 2015.

Djaenudin, D., Marwan, H., Subagjo, H., dan Hidayat, A. (2003). Petunjuk Teknis Evaluasi Lahan Untuk Komoditas Pertanian. Balai Penelitian Tanah - Pusat Penelitian dan Pengembangan Tanah. Agroklimat, Departemen Pertanian. Bogor.

Republik Indonesia. (2014). Undang-Undang Republik Indonesia Nomor 39 Tahun 2014 Tentang Perkebunan. Sekretariat Negara Jakarta. 